Article

\title{
Exploring Sustainable Aspects Regarding the Food Supply Chain, Agri-Food Quality Standards, and Global Trade: An Empirical Study among Experts from the European Union and the United States
}

\author{
Katja Pietrzyck ${ }^{1, *(D)}$, Sebastian Jarzębowski ${ }^{2}$ and Brigitte Petersen ${ }^{1}$ \\ 1 International Food Net Center, University of Bonn, Katzenburgweg 7-9, 53115 Bonn, Germany; \\ b.petersen@eqasce.de \\ 2 Institute of Agricultural and Food Economics-National Research Institute, ul. Świętokrzyska 20, \\ 00-002 Warsaw, Poland; sebastian.jarzebowski@ierigz.waw.pl \\ * Correspondence: katja.pietrzyck@uni-bonn.de
}

\section{check for} updates

Citation: Pietrzyck, K.; Jarzębowski, S.; Petersen, B. Exploring Sustainable Aspects Regarding the Food Supply Chain, Agri-Food Quality Standards, and Global Trade: An Empirical Study among Experts from the European Union and the United States. Energies 2021, 14, 5987. https://doi.org/10.3390/en14185987

Academic Editors: Karolina Pawlak and Dalia Štreimikiené

Received: 1 July 2021

Accepted: 17 September 2021

Published: 21 September 2021

Publisher's Note: MDPI stays neutral with regard to jurisdictional claims in published maps and institutional affiliations.

Copyright: (c) 2021 by the authors. Licensee MDPI, Basel, Switzerland. This article is an open access article distributed under the terms and conditions of the Creative Commons Attribution (CC BY) license (https:// creativecommons.org/licenses/by/ $4.0 /)$.
Abstract: Sustainability is increasingly a priority in the policies of the European Union, especially in the Common Agricultural Policy. This paper focuses on Sustainable Development Goals, the European Green Deal, and the Farm to Fork Strategy in an attempt to establish a relationship with the European Union's trade policy. Three selected components of the agri-food sector-the food supply chain, agri-food quality standards, and global trade-are examined in relation to defined sustainability aspects. The aim is to understand the interrelationship between the three components with specific regard to sustainability, to highlight their high complexity and current relevance, to contribute to systematic analysis in this area, and to present current progress. This qualitativeexplorative study is empirically supported by a survey of market experts, and the Transatlantic Trade and Investment Partnership between the European Union and the United States is used as an example. The results show the complexity between the relationships of the three components with a focus on sustainability and reveal a deep uncertainty. The most notable results are the limited level of knowledge and the insufficient attention from business representatives to sustainability aspects. Finally, the study identifies the state of integrating a sustainable perspective into European Union trade policy and provides suggestions for further research.

Keywords: agri-food industry; food safety; global supply chains; sustainable trade; quality management; quality standards; farm to fork strategy; European Green Deal; German chambers of commerce abroad; Transatlantic Trade and Investment Partnership (TTIP)

\section{Introduction and Background}

One of the most important economic sectors of the European Union (EU) is the production and trade of agricultural products and foodstuffs [1]. In this context, increasing globalization and market integration are becoming a vital concern. As a result, market structures are constantly changing, companies are experiencing increased competitive pressure, and export volumes are rising significantly [2], which is reflected in the EU trade policy [3]. Global agricultural trade is determined by a complex combination of international regulations, agreements, national laws, and requirements. These established regulations aim to ensure the safety of processes and products in the agri-food industry so that the quality and safety of food are guaranteed worldwide [4].

Food quality standards are effective throughout the process chain and are an essential tool for ensuring safe, standardized, and comparable processes and products in international trade [5-7]. Consequently, international quality standards are a key element for successful global trade. Nevertheless, they are considered non-tariff barriers to trade [8-11]. 
For this reason, there is a risk of complications occurring within the global food supply chain (FSC), for instance, double certification, no recognition of the product, origin identification, and labeling.

In recent years, the EU adopted a number of policies and strategies that address the international trade in agricultural and food products [1]. The most important of which is the EU's Common Agricultural Policy (CAP), which follows three paths to sustainability: social sustainability, environmental sustainability, and economic sustainability [12].

Regarding sustainable aspects in global trade, the European Commission (EC) presented a new trade and investment strategy called "Trade for all", in 2015, which included for the first time a sustainability chapter [13]. In 2018, the EC presented a 15-point action plan, which envisaged a new EU approach to trade and sustainability in its trade agreements and presented a comprehensive set of binding provisions and multilateral standards [14]. The topic of sustainability in trading will thus receive increased attention and obligations in the negotiation of free trade agreements (FTAs) [15].

The European Commission's priorities for 2019-2024 [16,17] include the European Green Deal (hereafter Green Deal) [18,19], of which the Farm to Fork Strategy (F2F strategy) is an integral part $[20,21]$ (Section 1.2).

\subsection{Background: Food Supply Chains}

We observe currently that FSCs, and in general, agribusiness systems, are transformed into a coordinated food system [22]. This leads to competition not only between individual companies in a food chain but also to competition between supply chains and networks $[23,24]$. Therefore, research on developing new models for food markets is required. In addition, there is an increase in consumers' demand on food safety and its functionality, consumers require product diversity, higher packaging quality, and the quality of services [25]. The protection of the environment and the economy of sustainable development is nowadays the most current trend [26]. Therefore, food production systems must be operated in a sustainable way [27]. Sustainable production and distribution systems should be implemented as more attention is paid to the relationship between sustainable development and the functioning of supply chains [28].

Sustainable supply chain management has become a focus for business practitioners and supply chain researchers [29]. Issues of climate change, geopolitics, labor conditions in emerging economies, and pressure from stakeholders and supply chain partners all play a role in shifting corporate focus toward the triple bottom line (TBL), the simultaneous achievement of environmental, social, and financial performance [30-35].

In conducting sustainable and responsible trading, it is important to know the market, generate sustainable knowledge, and establish stable FSCs. Sustainable FSCs in international trade activities have the potential to reduce environmental problems and the carbon footprint, mitigate greenhouse gas emissions, and promote responsible business and marketing practices, e.g., fair supply chains without the abuse of power [36].

Currently, sustainable FSC management includes various activities like strategy, risk management, organizational culture, quality and transparency $[33,37]$. The fundament of sustainable FSCs is to ensure policy coherence at the EU and national levels in agri-food policy. A number of research studies show that short FSCs (SFSCs) lead to sustainable behavior, albeit with complexities [38-40]. A meta-analysis published in 2013 found "that the degree of sustainability varies among different types of SFSCs, their products, locations, etc. Also, various participants in SFSCs may interpret sustainability differently and experience different impacts" [38] (p. 14). On the other hand, exporting is the driver of international cooperation, economic growth and prosperity [41-44]. Therefore, conducting mutual trade that is sustainable at all levels is essential. The literature has often observed a disruption in the flow along international FSCs because of, for example, differing quality standards, and frequently observed a change in valid standards. This results in wasted time, increased costs, and double certifications see, e.g., [34,45-49]. Thus, the process must be changed in a sustainable manner. 
This qualitative study empirically assessed this theory. For this, one section of the survey conducted in this study (Section 4.2.3.) determined the coordination processes with the trading partner along the supply chain using the example of an intended free trade agreement (FTA).

\subsection{Background: The European Green Deal and the European Farm to Fork Strategy}

The Green Deal marked a tremendous turning point in European sustainable policy. The developed strategies follow a broad approach to foster sustainability in agriculture. These include sustainable food production, sustainable food consumption, sustainable food processing and distribution, and prevention of food losses and waste. These changes could affect global agricultural commodity markets, as the EU is a major agricultural producer and participant in international agri-food trade relations $[18,19,50]$.

We observed that critical voices argue that the Green Deal could also be a potential non-tariff barrier to trade and could complicate further trade negotiations. In this respect, several studies highlight the potential impact of the Green Deal on international trade [50-54] and global dimensions (e.g., on the Global South) [50,55-59]. A currently published US study [50] considered, on the basis of three scenarios, the impact of the strategies over a period of 8-10 years. The results indicate that there will be a general reduction in trade activities in the agri-food industry. The results show eight effects due to the proposed measures: decrease in production, increase in food prices, increase in imports, decrease in exports, decrease in the gross income of farmers, increase in food costs, increase in food insecurity, and decrease in gross domestic product (GDP) [50]. In terms of the impact on international trade, it was predicted that all world regions would experience a decline of $2-4 \%$ as a result of the Green Deal [50] (pp. 12-16).

In May 2020, the EC published the F2F strategy [20,21] as part of the European Green Deal $[18,19]$ and made it mandatory for every EU member state, as per the CAP [12]. In addition, the F2F strategy is aligned with the Sustainable Development Goals (SDGs) of the United Nations (UN) [60-62].

The F2F strategy aims to increase the stability of the European food system in many facets and positively change their sustainable impact on third countries [63]. The strategy has a holistic approach and affects many sectors, from farming to food labeling. A comprehensive schedule with a time frame of 10 years defines the transition to a fair, healthy, and environmentally friendly food system in Europe. A key factor in this process for all stakeholders in the food system is gaining knowledge through education and training in achieving sustainable management and operations. The aim of the new European food policy is to implement concrete measures and targets for each stage of the food value chain to increase the stability of European food systems. The mission is to ensure sustainable food production and processing, as well as food safety, by promoting sustainable food consumption and diets, reducing food waste, and addressing food fraud $[20,21,63,64]$.

\subsection{Relationship with Sustainability}

At the global level, the F2F strategy aims to raise standards worldwide and reduce the environmental footprint by means of international cooperation and trade policy. Initiatives relevant to this study, which were presented by the EC, mainly concerned with economic sustainability, and intended to stimulate sustainable practices, are shown in Table 1 . These specific measures were organized with respect to the three main research aspects of this study, and some measures can be assigned to more than one main aspect. The interaction of the theoretical topics presented is illustrated by means of a relationship diagram (Figure A1).

We observed that investigations of sustainability aspects with regard to FSCs, quality standards in the agri-food sector, and global trade (exemplified by a free trade agreement) have rarely been conducted and analyzed in detail. In this context, there has been limited systematic research on the sustainability aspects of this topic. A recent bibliographic analysis of publications showed an increasing interest in sustainable food systems and 
revealed that publications in the field of policy and government on sustainable agri-food systems are overlooked [65] (pp. 13-14). Thus, we are aware that this issue is currently very topical and will continue to be relevant in the future. Our work contributes to the systematic analysis in this field and presents the current progress. Moreover, the aim of the online survey was to explore the opinions of trade experts in this context during the preparatory phase of the Transatlantic Trade and Investment Partnership (TTIP), a leading FTA between the EU and the United States (US). Although time has passed since then, transatlantic trade relations are still relevant today and the issues are still important, as we are not aware of any major changes or strong improvements.

Table 1. Initiatives to stimulate sustainable practices, divided into the three main research aspects.

\begin{tabular}{|c|c|c|}
\hline Practices in the Food Supply Chain & Practices in Food Quality Standards & Practices in Global Trade \\
\hline $\begin{array}{l}\text { Development of a contingency plan } \\
\text { (2021) for ensuring the food supply and } \\
\text { security in times of crisis }\end{array}$ & $\begin{array}{l}\text { Development of a contingency plan } \\
\text { (2021) for ensuring food supply and } \\
\text { security in times of crisis }\end{array}$ & $\begin{array}{l}\text { Proposal for the revision of the EU } \\
\text { legislation on food contact materials (food } \\
\text { safety, environmental footprint; 2022) }\end{array}$ \\
\hline $\begin{array}{l}\text { Develop an EU code and } \\
\text { monitoring framework for } \\
\text { responsible business and } \\
\text { marketing conducted in the FSC (2021) }\end{array}$ & $\begin{array}{l}\text { Stimulate reformulation of standards in } \\
\text { processed food }(2021 / 2020)\end{array}$ & $\begin{array}{l}\text { Proposal to require } \\
\text { origin indication } \\
\text { for certain products (2022) }\end{array}$ \\
\hline $\begin{array}{l}\text { Revision to EU marketing standards for } \\
\text { agricultural, fishery, and aquaculture } \\
\text { products to ensure the uptake and supply } \\
\text { of sustainable products (2021-2022) }\end{array}$ & $\begin{array}{l}\text { Proposal for the revision of the EU } \\
\text { legislation on food contact materials } \\
\text { (food safety, environmental footprint; } \\
\text { 2022) }\end{array}$ & $\begin{array}{c}\text { Promotion of global transitions caused due } \\
\text { to international cooperation }\end{array}$ \\
\hline $\begin{array}{l}\text { Proposal for a sustainable food labeling } \\
\text { framework to empower consumers to } \\
\text { make sustainable food choices (2024) }\end{array}$ & $\begin{array}{c}\text { Work through international } \\
\text { standard-setting bodies (e.g., Codex } \\
\text { Alimentarius) }\end{array}$ & $\begin{array}{c}\text { Inclusion of ambitious sustainability } \\
\text { chapter, including food, in all EU bilateral } \\
\text { trade agreements }\end{array}$ \\
\hline $\begin{array}{l}\text { Proposal to require } \\
\text { origin indication } \\
\text { for certain products (2022) }\end{array}$ & $\begin{array}{c}\text { Environmental aspects considered } \\
\text { when assessing requests for import } \\
\text { tolerances (e.g., standards for } \\
\text { pesticides) }\end{array}$ & $\begin{array}{l}\text { Environmental aspects considered when } \\
\text { assessing requests for import } \\
\text { tolerances (e.g., standards for pesticides) }\end{array}$ \\
\hline $\begin{array}{c}\text { Promotion of appropriate labeling } \\
\text { schemes- to ensure that food imported } \\
\text { into the } \\
\text { EU is gradually produced in a } \\
\text { sustainable manner }\end{array}$ & $\begin{array}{c}\text { Promotion of appropriate labeling } \\
\text { schemes-to ensure that food imported } \\
\text { into the } \\
\text { EU is gradually produced in a } \\
\text { sustainable manner }\end{array}$ & $\begin{array}{c}\text { Promotion of appropriate labeling } \\
\text { schemes-to ensure that food imported } \\
\text { into the } \\
\text { EU is gradually produced in a sustainable } \\
\text { manner }\end{array}$ \\
\hline
\end{tabular}

Source: own illustration based on Westhoek (DG SANTE) [64].

One of the characteristics of the agreement is the extent of the economic areas to be incorporated. The EU and the US have the most intensive trade relations in the world. Together, the two economies account for nearly half of the global gross domestic product, about $30 \%$ of global trade in goods, and about $40 \%$ of global trade in services. The focus of the study was not only on the situation in Germany, but also on the situations in the entire EU and the US. Furthermore, this empirical qualitative study addressed the experience of trade experts from the EU and the US in the development of an FTA while considering the quality standards and focusing on the awareness in the agri-food sector. This study also determined the current state of knowledge and compared the EU and US survey data. We used an online survey to address the questions. The purpose of this research is to understand the complexity of the defined determinants so as to have them considered in trade operations and treaty negotiations. The data allowed us to show the status-quo of knowledge and the impact of an FTA on bilateral trade between the EU and the US, taking sustainability aspects into account. In the following section, the empirical results are presented and discussed. The last section contains a conclusion and suggests further research. 


\section{Empirical Framework}

This empirical investigation is a pre-study to identify the role of quality standards in the agri-food sector in the negotiation phase of FTAs. The specific example of the TTIP, an FTA between the EU and the US, was applied because the TTIP is a critical example of a comprehensive FTA. The study design allowed us to compare the two negotiating partners and focus on sustainability aspects. Based on the SDGs and the F2F strategy, we defined and examined the nine sustainability aspects in Table 2 .

Table 2. Nine defined sustainability aspects (examined on the basis of the SDGs) addressed in the online survey conducted in the EU and US.

\begin{tabular}{lll}
\hline Sustainable Development Goals & \multicolumn{1}{c}{ Sustainability Aspects } \\
\hline & $\begin{array}{l}\text { 1. } \\
\text { 2. }\end{array}$ & $\begin{array}{l}\text { knowledge of trade, trade agreements, free trade } \\
\text { intercultural skills } \\
\text { education and training }\end{array}$ \\
3. & & \\
4. & 5. & agri-food quality standards \\
awareness for trade relations \\
prospects of international trade
\end{tabular}

Source: own description according to the SDGs [60-62].

For the empirical part of the study, we used data from an online survey undertaken by representatives of the member states of the EU and the US in 2016. The survey collected data on the trade activities in each country from the agri-food sector and reviewed the knowledge of trade experts.

The objectives of this study were as follows:

- $\quad$ Assess the trade situation between the EU and the US;

- Reflect qualified opinions on the subject matter;

- Explore the level of knowledge of TTIP;

- Frame the complexity;

- Consider the sustainability mindset; and

- Obtain the perspectives not only of Germany, but also of the entire EU, and the US.

\section{Materials and Methods}

\subsection{Profile of Survey Respondents}

For a qualitative and valid survey, independent experts engaged in the daily trading business were interviewed. Respondents were representatives of the foreign missions of the Federal Republic of Germany who work for the German Chambers of Commerce Abroad (AHKs). The AHKs represent the interests of the German economy worldwide, and the network comprises 140 locations in 92 countries. These membership organizations have approximately 45,000 membership companies worldwide. The mission and unique characteristic of the AHKs is to open access to international markets for German companies and build a connection with Germany for foreign companies. The AHKs represent the voice of the business community, provide a platform, offer the opportunity to establish valuable contacts, exchange information, attend events and organize specialist events, and act as liaisons with politicians. Moreover, the AHKs support export-oriented companies in the fields of market development, market entry, market presence, and market expansion. 
Mostly, the AHKs are the first point of contact in foreign markets for export-oriented companies [66-69].

For this survey, 22 AHKs located in EU member states were invited. In the US, the AHKs have three main locations, in Atlanta, Chicago, and New York, and two branch offices, in Philadelphia and San Francisco [70]. All these AHKs were invited to participate in the US part of the survey.

In addition, experts from the umbrella organization the Association of German Chambers of Industry and Commerce (DIHK), in Germany, and the Delegation of German Industry and Commerce (RGIT), in Washington D.C., which operates as the point of contact for transatlantic economic relations, were invited to participate in the survey [71-74]. All the institutions have been part of the German foreign trade promotion and co-funded by the German Federal Ministry for Economic Affairs and Energy (BMWi) [68]. All invited participants (i.e., men and women) were German native speakers. The selection of experts was not made randomly and arbitrary, but target-oriented and with the permission of each participant. For the qualitative knowledge acquisition, it was very important that the participants would have practical export knowledge and not just theory-based answers.

\subsection{Data Collection and Analysis}

The Delphi method was used for preparing the methodology and metrics (criteria for organizing and analyzing interviews). The Delphi method belongs to the group of heuristic methods in which the knowledge, experience and opinions of experts in a given field are used. The research consists of conducting a series of surveys among experts. The stages of the research in the Delphi method include: defining the problem, selecting a group of experts, preparation of the survey, analysis of feedback responses, development of results see, e.g., [75-79]. This study investigated the results of an online survey conducted in the EU member states and the US. The online survey was conducted by using the survey software "EFS Survey" from Questback GmbH through the academic program "Unipark." The survey was conducted by using a self-explanatory questionnaire (Section 3.3) in the German language, which was online for 6 weeks in April and May 2016. The experts were contacted individually by personal email and invited to participate in the online survey by clicking a direct link. Participation was voluntary, and responses were analyzed in accumulated form. The data export process and the descriptive statistics of the survey were conducted and analyzed, respectively, with Microsoft Excel. No software program other than Excel Software was used. For categorical and ordinal variables, absolute and relative frequencies were calculated. The exploratory study data are highly qualitative, as it involves a small group of experts who are important knowledge carriers in the field.

\subsection{Structure of the Questionnaire}

The design of the questionnaire was an important step because the wording of the questions had to be precise and in a structured form (see Supplement S2: Questionnaire and codebook). Based on previous research in the field, important topics were identified for the systematic preparation of questions. First, a prototype of the questionnaire was created with closed and open possible responses. Following this, the questions with the corresponding proposed responses were tested by researchers and master's students. Then we simulated the complete online survey. When the final version of the questionnaire was created, the questions were made more precise and the time required was recorded. This procedure was repeated several times. To structure the analysis, the empirical model was fragmented into the three defined groups and examined with regard to the sustainable aspects of international trade, the characteristics with a focus on quality management (QM) and various attributes of the FSC. The first group of questions was related to knowledge of TTIP (seven questions). The second group of questions aimed to capture the link between $\mathrm{QM}$, trade, and economic growth (five questions). The last group of questions shows the topics of FSC (five questions). In the end, four general closing questions were asked. The questionnaire comprised 21 questions, with closed and open questions, and was validated 
by a consistency check and time exposure analysis. For each question, open text fields were provided to clearly express the opinion. Furthermore, the questionnaire contains two filters, one for the survey of the US-AHKs and one for the EU-AHKs, to tailor the questions to the target group. In the introductory part of the questionnaire, the research project was briefly introduced to inform the respondents about the topic and purpose of the research, as well as the timeframe to complete the survey, which was approximately 10-20 min.

\section{Results and Discussion}

The tables and figures in this section outline the empirical findings of the online survey regarding the nine sustainability aspects examined based on the SDGs and the TTIP by comparing the EU and the US.

\subsection{Survey Respondents}

Table 3 shows the number and allocation of all survey respondents. Notably, 26 participants from 19 locations completed the survey. Overall, the quota of $65.5 \%$ was significant. The difference between the participating locations and the sample size was due to allowing different departments of an individual AHK to participate, for example, the CEO, the agri-food experts, or the legal department.

Table 3. Overview of the frequency of participation.

\begin{tabular}{ccccc}
\hline Focus Group & $\begin{array}{c}\text { Locations } \\
\text { (Potential Participants) }\end{array}$ & $\begin{array}{c}\text { Participated } \\
\text { Locations }\end{array}$ & Quota & $\begin{array}{c}\text { Total } \\
\text { Participants }\end{array}$ \\
\hline EU-AHKs & 22 & 13 & $59 \%$ & 18 \\
US-AHKs & 5 & 4 & $80 \%$ & 6 \\
DIHK & 1 & 1 & $100 \%$ & 1 \\
RGIT & 1 & 1 & $100 \%$ & 1 \\
\hline Total & 29 & 19 & $65.5 \%$ & 26 \\
\hline
\end{tabular}

Source: own calculation. EU, European Union; AHKs, German Chambers of Commerce Abroad; US, United States; DIHK, Association of German Chambers of Industry and Commerce in Germany; RGIT, Delegation of German Industry and Commerce, in Washington D.C., US.

\subsection{Results for the Defined Sustainability Aspects}

\subsubsection{Results for SDG 4-Quality Education}

The following results reflect the collected data on sustainable aspects $1-3$ related to education. Accordingly, the data were examined in terms of (1) knowledge of trade, trade agreements, and free trade; (2) intercultural skills; and (3) education and training (Table 2).

Participants were asked how they rate the level of information on the TTIP negotiations and the content of the TTIP agreement. A comparison was made between the general public of the EU and the US as well as business professionals of the EU and the US. The findings on the level of information on the trade agreement TTIP (Table 4) imply that the general public of the EU (very low level of information ranked 70.6\%) and the US (very low level of information ranked 57.1\%) are not well informed about the TTIP negotiations and the content of the TTIP agreement. By contrast, the business professionals in the EU (intermediate level of information ranked 36.8\%) and the US (intermediate level of information ranked $57.1 \%$ ) are on an intermediate level of information. Thus, we came to the result that probably the business community is better informed than the mainstream of society. One reason for this phenomenon could be that both groups (according to the experts) are only informed by secondary sources and that both groups considered their access to information as generally very difficult. Moreover, a lack of transparency was criticized by the surveyed participants and therefore an increase in the level of transparency was required. 
Table 4. Comparison of the level of information on TTIP negotiations and content of TTIP agreement in the EU and US general public and business professionals.

\begin{tabular}{ccccc}
\hline $\begin{array}{c}\text { Level of } \\
\text { Information }\end{array}$ & $\begin{array}{c}\text { EU General } \\
\text { Public } \boldsymbol{n = 1 7}\end{array}$ & $\begin{array}{c}\text { US General } \\
\text { Public } \boldsymbol{n = 7}\end{array}$ & $\begin{array}{c}\text { EU Business } \\
\text { Professionals } \boldsymbol{n = 1 9}\end{array}$ & $\begin{array}{c}\text { US Business } \\
\text { Professionals } \boldsymbol{n = 7}\end{array}$ \\
\hline very high & $0 \%$ & $0 \%$ & $5.3 \%$ & $14.3 \%$ \\
high & $0 \%$ & $0 \%$ & $5.3 \%$ & $28.6 \%$ \\
intermediate & $17.6 \%$ & $0 \%$ & $\mathbf{3 6 . 8} \%$ & $\mathbf{5 7 . 1 \%}$ \\
low & $11.8 \%$ & $42.9 \%$ & $31.6 \%$ & $0 \%$ \\
very low & $\mathbf{7 0 . 6 \%}$ & $\mathbf{5 7 . 1 \%}$ & $21.0 \%$ & $0 \%$ \\
\hline
\end{tabular}

Source: own calculation. The bold font denotes the highest values. TTIP, Transatlantic Trade and Investment Partnership; EU, European Union; US, United States.

As aforementioned, survey respondents perceived gaining access to information as difficult. Generating knowledge requires information sources that report correctly and comprehensively on a specific topic, supported by facts $[74,80,81]$. For this reason, survey respondents were asked what source of information they typically use to obtain information and use as a basis for decision support.

The following sources of information were mentioned:

- The mainstream press and public media (e.g., local daily newspapers and the business press);

- Government institutions, e.g., the EC, Ministry of Agriculture, Ministry of Economy of the respective European country, US Administration, and US trade representatives;

- Local economic associations; and

- Business websites and other recommended websites.

On the basis of the cited sources of information, assessing the quality is difficult, but notably, the sources are largely secondary. This result allows us to conclude that the level of information on the TTIP negotiations and the content of the TTIP agreement among companies and experts should increase and that organizations should increase their efforts in gathering information to avoid information asymmetries.

The analysis of export competence in EU and US companies revealed similar results. Participants were asked to assess the level of export knowledge among AHK member companies. Notably, the level of expertise was rated as minimal to good (Table 5). The results imply that the knowledge and global market intelligence of the member companies must be improved in a sustainable manner.

Table 5. Comparison of the degree of export knowledge in relation to the EU and US market; degree of knowledge: strong $(+++)$, medium $(++)$, low $(+)$, weak (-).

\begin{tabular}{ccccc}
\hline & $\begin{array}{c}\text { Very Good } \\
\text { Knowledge }\end{array}$ & $\begin{array}{c}\text { Good } \\
\text { Knowledge }\end{array}$ & $\begin{array}{c}\text { Minimal } \\
\text { Knowledge }\end{array}$ & $\begin{array}{c}\text { No Knowledge } \\
\text { Present }\end{array}$ \\
\hline EU companies & - & +++ & +++ & - \\
US companies & + & - & ++ & - \\
\hline
\end{tabular}

Source: own calculation. EU, European Union; US, United States.

Relationships with individuals from other cultures play an important role in sustainable trade relations along the FSC. In international business settings, intercultural distinctions are often perceived as obstacles in negotiating and developing a fruitful trade partnership. Therefore, this topic relates particularly to education and training and thus the learning of cross-cultural skills, solutions and international business communication [82-86]. In our investigation, this issue plays an important role in the customersupplier relationship, discussed in Section 4.2.3.

Furthermore, the experts were asked about education and training in the field of QM regarding global trade relations. They reported (open text boxes of the questionnaire) that the EU and the US have a shortage of specialists in this area or a fear that a shortage could occur; therefore, training and staff development initiatives were rated as very important. 
There was approval among the experts that QM training should focus on the various standards and certification mechanisms so that professionals would be sensitized to the subtleties and complexities and understand the complex interrelationships so that they could use them as a decision-making tool in their day-to-day work. In this context, the experts believed that the harmonization of international standards might reduce the level of difficulty of education in QM. Recommendations for international education and training concepts in QM, especially in the agricultural and food sector, have been frequently discussed and conceived, and corresponding programs have been established [87-89]. Nowadays, challenges still remain in the implementation of the concepts and the application of customized solutions. Due to permanent change, the concepts must be constantly modified and adjusted. The impact of the SARS-CoV-2 pandemic has uniquely exemplified the challenges of QM, the risks to FSCs, and the consequences for global food systems [65,90-94]. For sustainable education and training, the concept of lifelong learning and capacity building should be the focus [95-97]. In this context, we highlight a quote by Quendler et al. [96]: "Globally speaking education is a beautiful, complex, and intricate tapestry in its own right. Many challenges of sustainable development go hand in hand with individual human needs, the solution to which is part of a process of human-centered education. Underlying this vision is the assumption that investing in education can create "manifold dividends" for the SDGs and ensure job opportunities for the next generations. Investment in education and technological change is essential to support this vision".

\subsubsection{Results on SDG 8-Economic Growth}

To understand the economic context for the agri-food sector, we empirically assessed sustainable aspects 4-6. For this purpose, knowledge of (4) international quality standards were surveyed; (5) awareness for trade relations was assessed; and opinions on the (6) prospects of international trade were evaluated (Table 2).

Consequently, participants were asked about their perceptions of the role of international quality standards in global trade. The focus was on the temporal difference between the current situation and the role after the enforcement of TTIP. Table 6 shows no difference between the EU and the US. Both groups reported that the standards play a very large role at the moment and that the role will not significantly change after the TTIP is enforced. None of the respondents opined that international quality standards are not relevant in global trade. In summary, the most important question on the role of international quality standards was answered clearly. The participants agreed that the international quality standards have a major role in global trade at any time.

Table 6. Comparison of the EU and the US on the role of international quality standards in global trade during the TTIP process.

\begin{tabular}{|c|c|c|c|c|}
\hline & A Very Large Role & A Major Role & A Medium Role & A Minor Role \\
\hline EU: at the moment $(n=16)$ & $43.75 \%$ & $43.75 \%$ & $12.5 \%$ & $0 \%$ \\
\hline US: at the moment $(n=3)$ & $33.3 \%$ & $33.3 \%$ & $33.3 \%$ & $0 \%$ \\
\hline EU: TTIP in force $(n=15)$ & $20 \%$ & $46.67 \%$ & $13.3 \%$ & $20 \%$ \\
\hline US: TTIP in force $(n=4)$ & $25 \%$ & $50 \%$ & $0 \%$ & $25 \%$ \\
\hline
\end{tabular}

Source: own calculation. The bold font denotes the highest values. EU, European Union; US, United States; TTIP, Transatlantic Trade and Investment Partnership.

For a more intensive assessment of the role of the quality standards, the experts were asked to what extent they assessed the degree of dissemination of the most important quality standards. A difference was made between the international standards of the DIN EN ISO Group and the most known private standards. As a result, only the statements of the EU experts could be evaluated (Figure 1), because the data of the US participants could not be represented graphically, due to the small sample size. All the quality standards surveyed were rated as not widely used or barely used, because other standards are prevalent in the US. The result shows that there are different assessments of the dissemination and thus the 
application of the quality standards known in the EU. With respect to the dissemination rate of quality standards in the EU, notably, the DIN EN ISO standards are widespread, according to this survey. Participants reported International Featured Standards (IFS) as the most frequently used private standards (Figure 1). The respondents explained further that in the US, equivalent standards are applied.

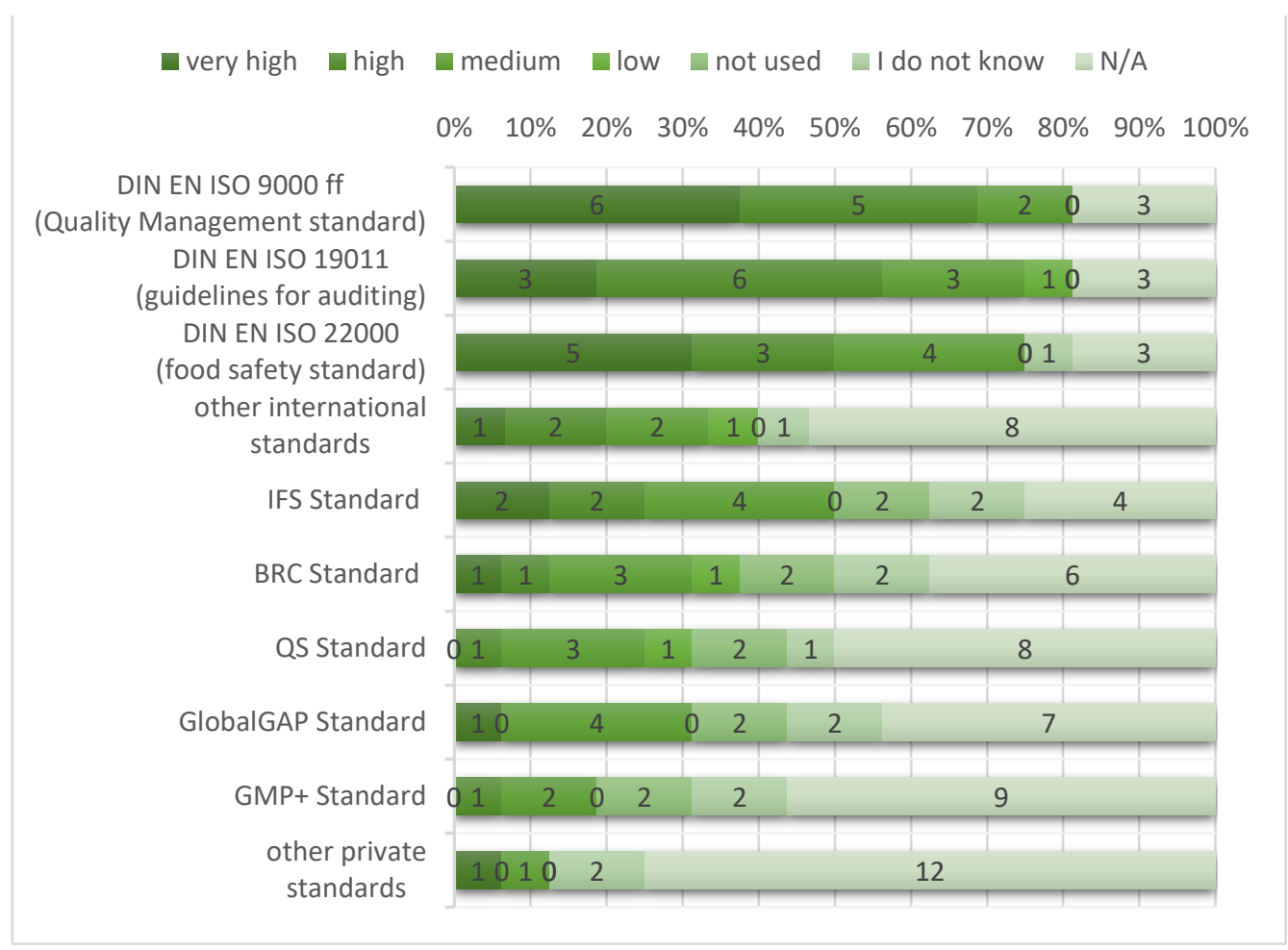

Figure 1. Presentation of the dissemination rate of international quality standards and private standards in the European Union. Multiple answers were possible; $n=159$. Source: own calculation.

In addition, participants were asked to estimate what percentage of companies in the EU and the US are certified to international quality standards. On the basis of the responses, a mean of $48 \%$ was calculated for the EU, and a mean of $43.75 \%$ was calculated for the US. This finding implies that the experts surveyed assumed a certification level of their member companies of less than 50\%, i.e., less than half of the known companies fulfilled international quality standards to date.

Overall, the survey revealed substantial knowledge gaps in this area. Respondents were often not aware of the differences between international quality standards and private standards or did not understand them as different basic elements in certification. As a trend, both comparison groups revealed that organic standards are widespread and that their prevalence is increasing.

For sustainable success in global trade and for generating economic growth, trade relations between countries must be recognized within a company, and a strong awareness of trade relations must be implemented in day-to-day business. To obtain opinions on this point, the survey asked the experts about their awareness of trade relations and the TTIP. Basically, a high awareness among EU companies, but with a tendency to a decrease in awareness, was observed (Table 7). By comparison, the US results show a solid, high awareness. Therefore, awareness should be increased and then sustainable economic business success could be achieved. 
Table 7. EU and US companies' awareness of TTIP.

\begin{tabular}{ccccccc}
\hline & $\begin{array}{c}\text { Very High } \\
\text { Awareness }\end{array}$ & $\begin{array}{c}\text { High } \\
\text { Awareness }\end{array}$ & $\begin{array}{c}\text { Neutral } \\
\text { Awareness }\end{array}$ & $\begin{array}{c}\text { Low } \\
\text { Awareness }\end{array}$ & $\begin{array}{c}\text { Very Low } \\
\text { Awareness }\end{array}$ & n/a \\
\hline EU $(n=19)$ & $0 \%$ & $\mathbf{2 6 . 3 \%}$ & $21.1 \%$ & $21.1 \%$ & $15.8 \%$ & $15.8 \%$ \\
US $(n=7)$ & $14.3 \%$ & $\mathbf{4 2 . 9 \%}$ & $28.6 \%$ & $0 \%$ & $0 \%$ & $14.3 \%$ \\
\hline Source: own calculation. The bold font denotes the highest values. EU, European Union; US, United States.
\end{tabular}

One of the most important questions regarding sustainable economic growth was which companies would benefit from an FTA. To illustrate an answer to that question, we used the example of the TTIP. In the EU, companies are classified into four groups according to the number of employees: (1) micro-companies (fewer than 10 employees), (2) small companies (10 to 49 employees), (3) medium-sized companies (50 to 249 employees), and (4) large companies (as of 250 employees) [98]. On the basis of this classification, the experts were asked to assess the situation. As shown in Figure 2, the attitudes of the survey participants were different. The respondents from the US reported that micro, small, and medium-sized companies together would benefit more than large companies would. By contrast, the European experts did not consider the opportunities for small companies to be positive and posited that micro-companies and small companies would benefit the least. Notably, $59 \%$ of the Europeans believed that only large companies would take advantage of TTIP. The US experts assessed this point differently than their EU counterparts: the former $35 \%$ believed that only the large companies would benefit. Overall, Figure 2 shows that per the experts, large companies would be the beneficiaries of an FTA.

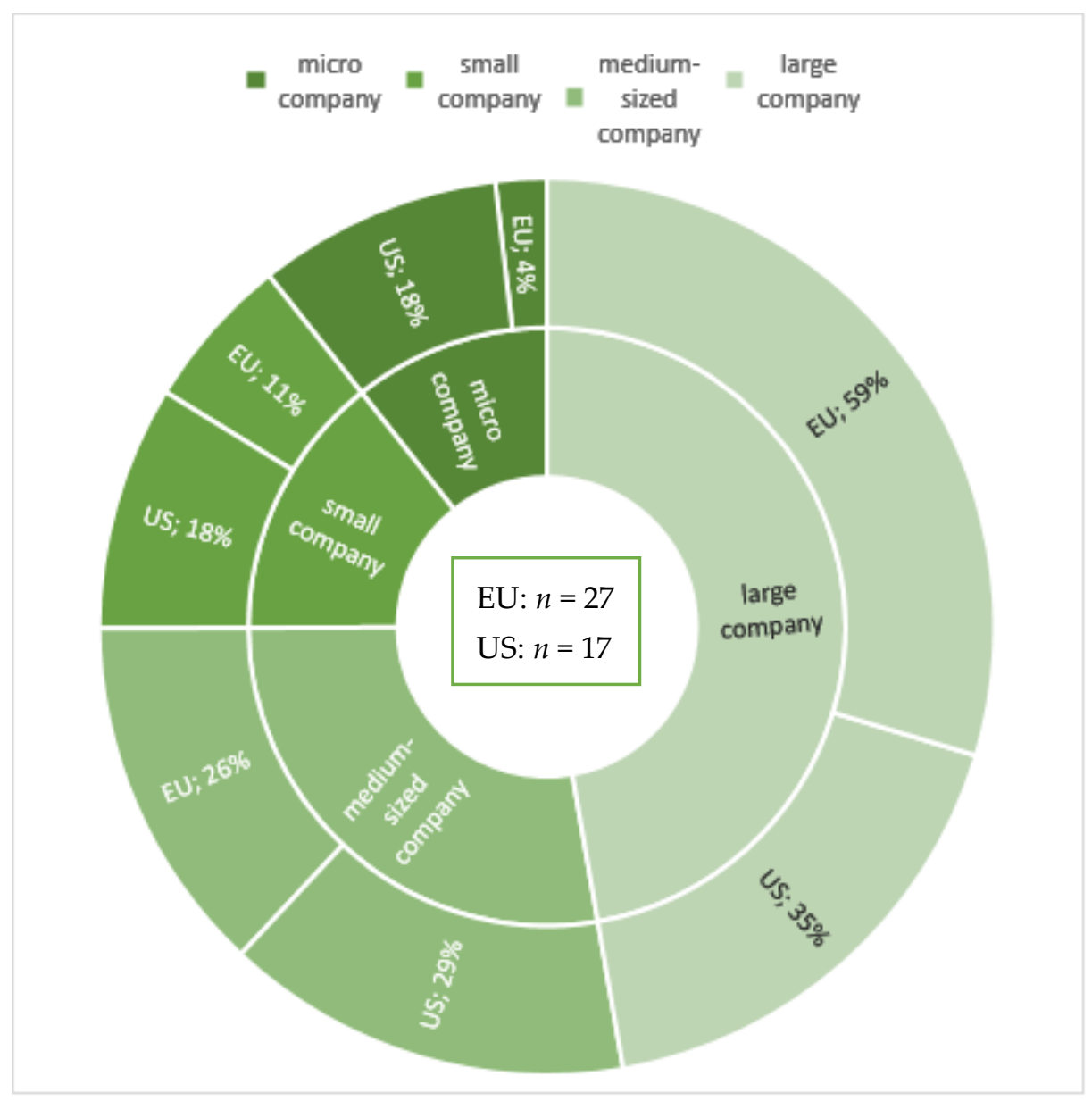

Figure 2. Companies that would benefit from the TTIP. Multiple responses were possible. Source: own calculation. 
Another essential question on this area of sustainable economic growth was: Who would be the winners and losers of the agri-food industry due to the enforcement of the TTIP? In developing the question, the most relevant export products and industries of the agri-food sector were included; in the food sector, these were the following: non-alcoholic beverages, alcoholic beverages, meat and sausage products, fruits and vegetables and potatoes, dairy products, sweets and confectionery and salty snacks, bread and pastry products and mills, and all other food products. Among the agricultural industries, the following branches were included: agricultural engineering and machinery, feedstuff products, livestock breeding, and plant cultivation.

The results are shown in Figure 3. The Europeans reported that the sector of agricultural engineering and machinery would benefit the most. Good opportunities were also predicted for the beverage industry and the meat sector. However, they did not report either winner or a loser. By contrast, the respondents from the US reported that the TTIP was positive for industries overall; additionally, they predicted that mainly alcoholic beverage and meat products would be the winners and that the branches of the agricultural sector would have good chances.

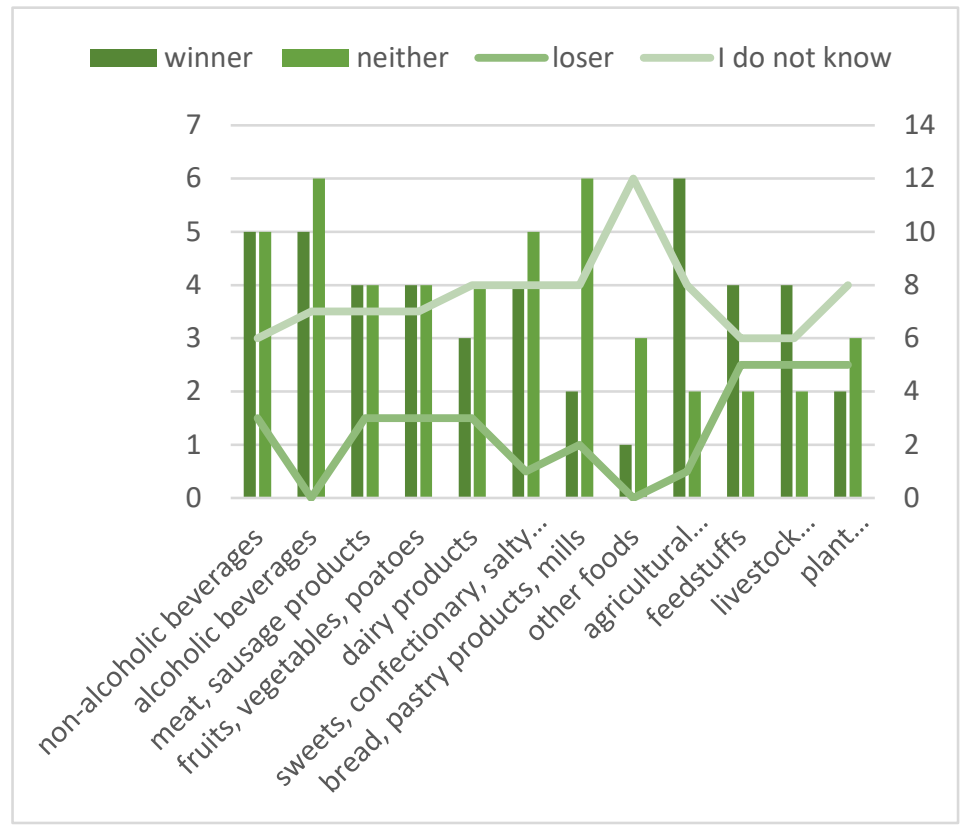

(a) EU

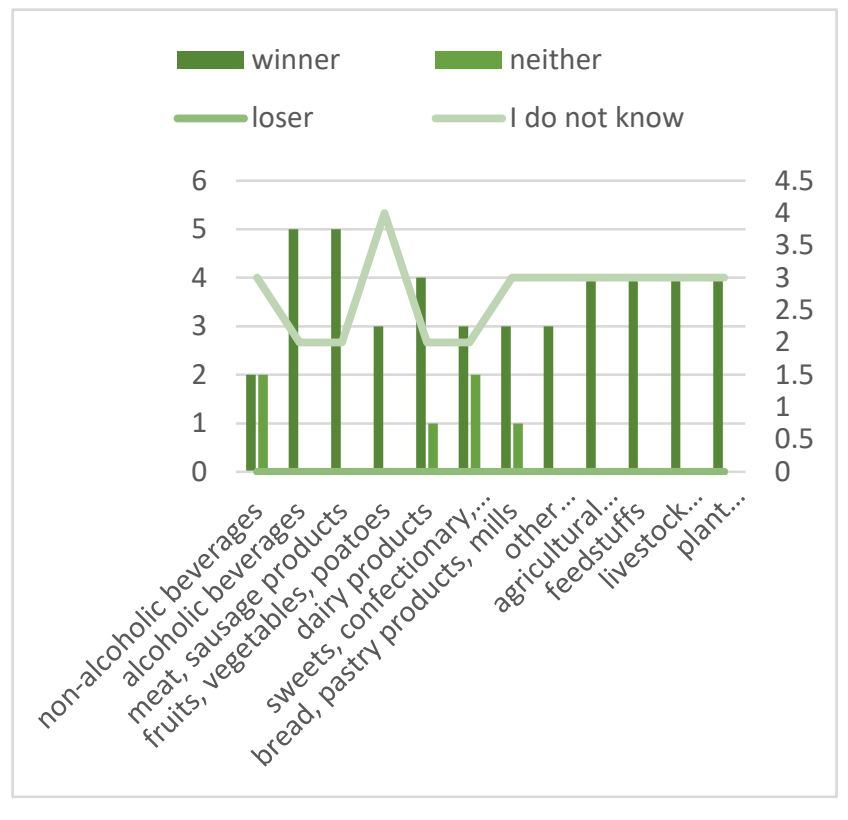

(b) US

Figure 3. Winners and losers of the TTIP: (a) in the EU; (b) in the US; absolute values. Source: own calculation.

\subsubsection{Results for SDG 9 and SDG 12-Industry, Innovation, Infrastructure, and Responsible Production}

This part of the study mainly refers to the (7) resilience of the FSCs and the (8) customer-supplier relationship, each in the context of (9) the international quality standards (Table 2). The survey results show that at the time of the survey (before the SARS-CoV-2 pandemic), the respondents reported that the state of the FSCs from the EU to the US and vice versa was fundamentally stable and sustainably resilient.

Because international and private quality standards are classified as non-tariff barriers to trade [8-11], survey respondents were asked about their experiences with complications within the global FSC. The results indicate that there have been sporadic interruptions in the FSC due to existing quality standards. The reported interruptions or extensions of deliveries were mainly caused by incorrect certification documents for organic products. Furthermore, the survey participants stated that FSCs could be interrupted if maximum residue levels (MRL) of plant protection products, especially pesticides, are exceeded or if plant protection products are used that are not approved in the destination country. In 
the EU, tolerance levels are an important concern, both for imports from the US to the EU and for exports from EU countries to the US. For example, survey participants mentioned EU-produced stone fruit (cherries, peaches, and nectarines), mainly cherries from Poland, which are constantly monitored $[99,100]$.

The opinion of Polish companies of the agri-food sector on global trade and the TTIP was investigated by us through a separate study, where the main objective was to analyze Poland's trade position and its domestic political interests. The results of that study showed a similar opinion of the Polish experts as these present results of this current paper [101]. Our previous study contained the analogical research framework and questionnaire and is therefore comparable.

The participants also reported that in QM, trust in the individual business partners along the entire value chain is of substantial importance. Transparent quality concepts and structures, which can be quickly adapted, if necessary, are an important criterion for trust-building cooperation [102].

The respondents further indicated that an FTA between the EU and the US is not expected to significantly change FSCs. However, changes in the customer-supplier relationship along the entire value chain were predicted (Figure 4). Most European respondents expected the coordination process with US partners to not change much. Again, some people were concerned that when the FTA is enforced, the coordination process with business partners would increase from slightly to greatly; thus, an increased workload was expected. By contrast, the US participants expected the coordination process along the FSC to reduce slightly.

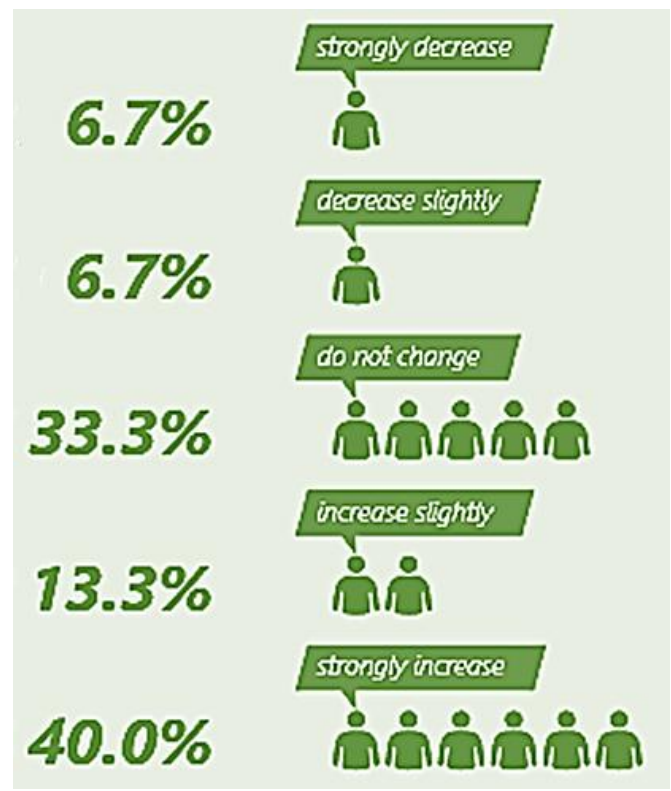

(a) EU survey respondents $(n=15)$

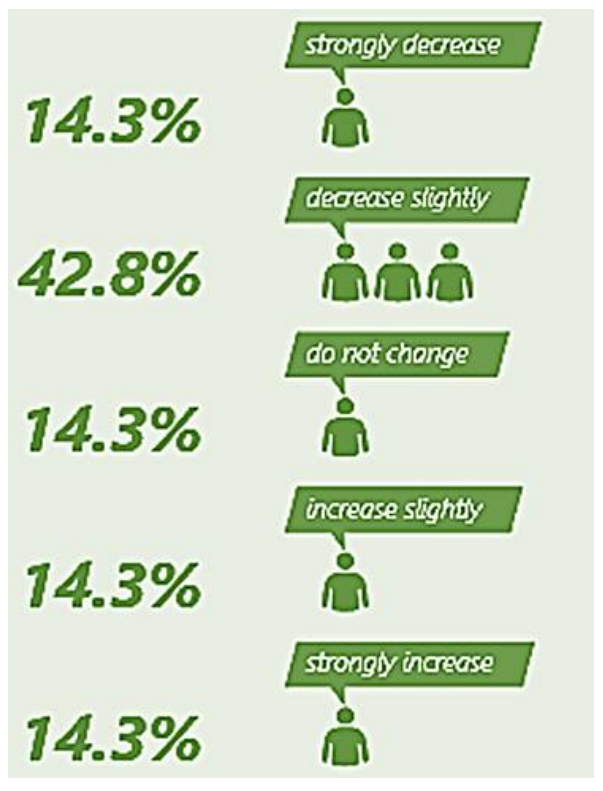

(b) US survey respondents $(n=7)$

Figure 4. For companies in the EU (a) and the US (b), the expected shifts in the coordination process of the customer-supplier relationship along the FSC regarding the TTIP; absolute and percentage values. Source: own calculation.

Some participants indicated that cultural differences also play a role in business relationships, due to which the supply chain has been disrupted. In this respect, the experts described different approaches to negotiating in the business process. For instance, some suppliers are "straight to the point", but others expect small talk before the negotiations begin. Thus, gaining knowledge of country-specific negotiation management is particularly important for sustainable business success. Individuals in the US expected those in the EU to have an excellent marketing concept for their products. According to the experts' 
self-assessment, some Eastern European countries have shown weaknesses in product marketing and should establish a sustainable marketing strategy.

From the experts' point of view, different philosophies, especially regarding food regulations linked to quality standards, are the most important issues affecting why FSCs are blocked. Thus, the respondents stated that the level of acceptance of the producing and processing processes differs, for example, in the preventive use of antibiotics. At the root of this discrepancy is the fundamentally different approach of the two partners to risk management: the EU's precautionary principle as opposed to the scientific approach of the US. Further bottlenecks in the FSC are often product labels, e.g., genetically modified materials (GMO), preservatives, artificial colors, and flavors.

With regard to the infrastructural aspect of cold chain management, this was considered unproblematic by the experts because interruptions affecting the cold chain were rarely recorded.

For strengthening the FSCs in the long term and making global trade relations more internationally coherent (e.g., more compatible, economical, reliable, and sustainable), survey participants suggested the following options and special needs for export-oriented companies:

- Continually reduce trade barriers and other protectionist measures;

- Fund (from the government) the opening of new export markets, market monitoring, and mentoring in the market entry phase and export promotion programs;

- Harmonize technical standards;

- Harmonize approval procedures along the global FSC;

- Simplify regulations (e.g., clear wording on the legal requirements of ingredients, processes, declarations, and consumer guidelines);

- Defend the Agreement on the Application of Sanitary and Phytosanitary Measures (SPS Agreement);

- Increase transparency, especially in the negotiation contents of FTAs;

- Agree to a memorandum of understanding at the intergovernmental level;

- Strengthen the establishment of international partnerships in the private and public sectors (to promote private-public partnerships);

- Adopt strict, uniform consumer protection guidelines;

- Improve the links between academia and industry;

- Strengthen established international partnerships between industry and government;

- Receive additional governmental support for research and development;

- Provide a global platform for exchanging best practices and model projects; and

- Supporting capacity building and education.

The list presented contains no order of priority, as the importance of each need is equal.

The mentioned special requirements for sustainable global trade clearly indicated the interdependencies and the relationship between the three selected components of the agri-food sector-the food supply chain, agri-food quality standards, and global trade. We observed that some of the requirements of the business experts were implemented in the new EU trade strategy, which is important for the agri-food sector.

The EC's 15-point action plan, launched in 2018, conceptually integrated some of the issues and established a set of binding provisions and multilateral standards [14]. The plan also generates more attention and commitments to sustainability in FTA negotiations [15]. In addition, an experts' group on trade and sustainable development has been attempting to resolve the concerns and implement the 15-point action plan [103]. Particularly remarkable is the EU's willingness to strengthen innovations, setting up of partnerships and cooperation with international organizations and the mutual setting of standards, establishment of responsible business practices, increase in funding, and increase in transparency and improving communication by involving civil society. Hence, the measures align with the demands of the experts surveyed in this study. Thus, the EU is aware of the problems experienced by business representatives.

Due to the SARS-CoV-2 pandemic and the objectives of the Green Deal $[18,19]$, a public consultation was conducted in 2020 to review trade policy. This process was followed by 
the presentation of the new EU trade strategy in February 2021 [104]. In the context of this review, the topic "Enhancing resilience and sustainability of value chains" is of particular importance for the agri-food sector. The primary objective is to promote sustainability standards across global value chains. Other EU priorities are to strengthen cooperation in Green Deal-related activities, particularly biodiversity, sustainable food policy, environmental protection, and the circular economy. [105] (pp. 15-18).

"The Commission will pioneer work on developing standards for sustainable growth and shape international standards in line with the European Green Deal, while engaging with its partners to develop and implement rules that are similarly ambitious" [105] (p. 17).

In addition, regulatory cooperation at the international level must be further strengthened, and international standards will be further developed with the cooperation of standard-setting bodies [105] (pp. 19-20).

\section{Conclusions}

The purpose of this research was to understand the relationship and the complexity of the defined three components of the agri-food sector, the food supply chain, agri-food quality standards, and global trade regarding sustainability. We used an empirical survey, which aimed to explore the opinions during the preparatory phase of the TTIP of EU and US trade experts on the defined nine sustainability aspects (Table 2) examined on the basis of the SDGs. The data available from the online survey allowed us to show and compare the level of knowledge on the TTIP negotiations and the content of the TTIP agreement, and the impact of an FTA (in this case, the TTIP) on bilateral trade between the EU and the US by considering sustainability aspects. The comparison between the EU and US participants was conducted to investigate the differences in attitudes and knowledge levels. In addition, the following question arose: What expectations and requirements do trade agreements set for trade operations of agri-food sectors? The results were similar to those we expected, which were derived from our experience of three other studies conducted as part of our research [101,106,107]. Notably, we found evidence for significant differences in participants' attitudes: the US participants were noticeably more positive than their EU counterparts about the expectations of an FTA.

Additionally, the results framed the complexity of the relationship between global FSCs, quality standards, and aspects of global trade in the agri-food sector. The outcomes reveal a deep uncertainty, limited knowledge, and insufficient attention to this issue; a sense of uncertainty was evident in global market intelligence.

The results show that the selected sustainability aspects play an immensely important role for the three components under investigation. Successful global trade of agri-food products along the FSC can only be achieved by integrating elements of quality management and considering sustainability.

The analysis is not exhaustive but reflects multiple factors that shape sustainability measures, particularly in the areas of FSCs, quality standards, and global trade in agricultural products and food. The limitation of this survey was that the sample of experts was small. Eventually, survey respondents identified specific necessities and expressed precise needs for sustainable trade in agri-food products.

The aspects of EU trade policy led us to the general conclusion that there is a strong intention to further develop and strengthen the sustainability aspects examined in this study. In sum, our findings reveal particularly important approaches for policymakers and quality managers. However, discussions of education and capacity building are limited in the EU institutions in this surveyed context, even though it being an SDG. In times of crisis, it is crucial to employ well-trained specialists in the agri-food sector along the entire value chain to guarantee the general high quality of food.

Moreover, this paper exemplified the EU's free trade negotiations with the US with regard to the agri-food sector. We observed that the EU's approach to global trade in agri-food products is currently facing some of its greatest challenges ever. This is not only a result of the SARS-CoV-2 pandemic, but also of protectionism, and likewise the great 
demands for continued adaptation to global structural changes in global trade. However, recent discussions among experts indicate that due to the new Biden administration, there is currently a positive atmosphere and favorable business climate between the EU and the US. This positive business climate could be used by policymakers to build new mutual trust and relaunch transatlantic relations, as well as to agree on restarting negotiations of an FTA. By collaborating closely, new and novel ideas could be developed, for example, in the area of food safety in the biotechnology sector. Additionally, we perceive a trend towards more FTAs between the EU and third countries and therefore a necessity for high-quality standards to ensure food safety in global trade.

Finally, because of the attitude of market experts in the AHKs, we suggest that further research should focus on sustainable FSCs regarding global trade and the agri-food quality standards and their relations in the context of responsible acting. One possible line of further research could be deepening the analysis of the types of EU trade partners. In addition, comparisons of other EU free trade agreements with third countries could provide further insights into the mechanisms of international trade activities with regard to sustainability aspects. Overall, additional attention should be paid to agri-food quality standards in national and international research and policy agendas.

Supplementary Materials: The following are available online at https:/ /www.mdpi.com/article/10 .3390/en14185987/s1, Supplement S1: List of abbreviations and acronyms; Supplement S2: Questionnaire and codebook.

Author Contributions: Conceptualization, K.P. and S.J.; methodology, K.P.; software, K.P.; validation, K.P. and S.J.; formal analysis, K.P.; investigation, K.P.; resources, K.P., S.J. and B.P.; data curation, K.P.; writing—original draft preparation, K.P. and S.J.; writing—review and editing, S.J.; visualization, K.P.; supervision, B.P.; project administration, K.P. All authors have read and agreed to the published version of the manuscript.

Funding: This research did not receive any specific grant from funding agencies in the public, commercial, or not-for-profit sectors. It was financed by the core budget of Prof. Petersen.

Institutional Review Board Statement: The study was conducted according to the data privacy agreement (University of Bonn, 38/2018).

Informed Consent Statement: Not applicable.

Data Availability Statement: The data presented in this study are available on request from the corresponding author.

Acknowledgments: Submitted as part of the thesis of K. Pietrzyck to the Faculty of Agriculture of the Rheinische Friedrich-Wilhelms-University Bonn, Bonn, Germany, 2021. The authors would like to thank the participants of the AHK World Conference 2016 in Berlin for their numerous and exceptionally helpful remarks as well as all participants of the online survey.

Conflicts of Interest: The authors declare no conflict of interest. 


\section{Appendix A}

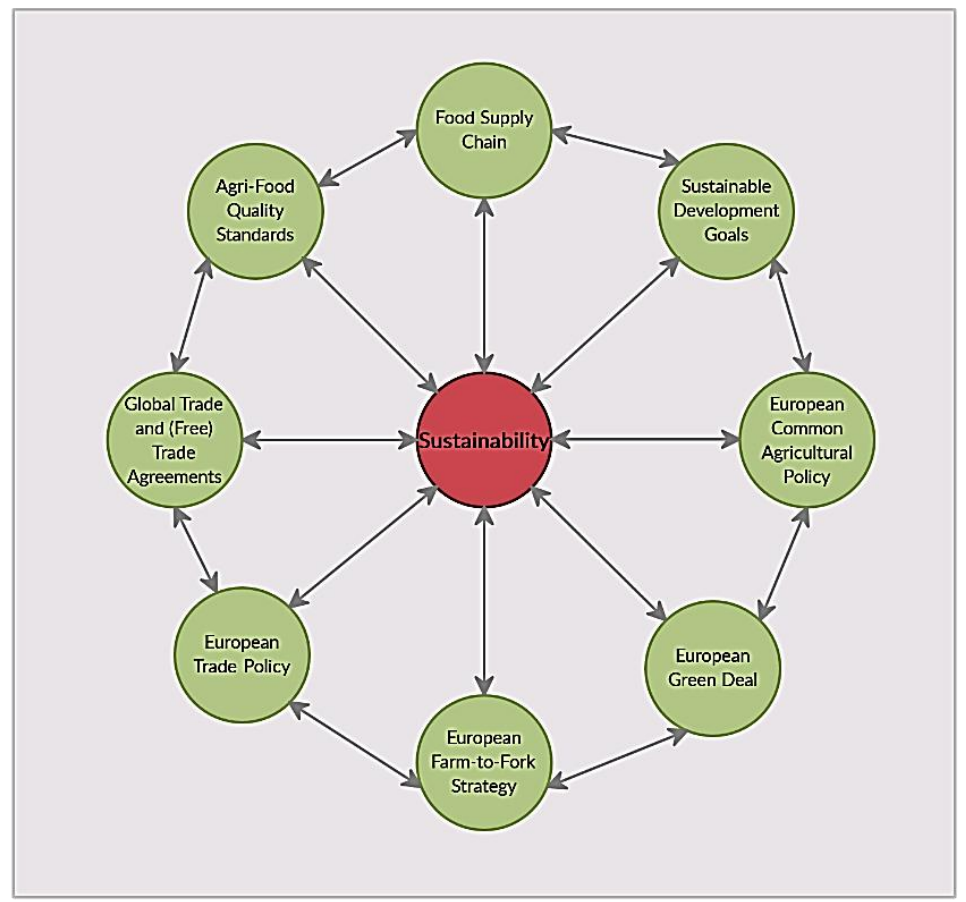

Figure A1. Relationships among the theoretical topics. Source: own illustration.

\section{References}

1. European Commission. Agri-Food Markets. Available online: https://agridata.ec.europa.eu/extensions/DataPortal/ agricultural_markets.html (accessed on 22 February 2021).

2. European Commission. Trade in Value. Factsheets on EU Countries Agri-Food Trade with the World, Individual Countries and Selected Regions. Available online: https: / /ec.europa.eu/info/food-farming-fisheries/farming/facts-and-figures/markets / trade/trade-country-region/trade-value_de (accessed on 26 February 2021).

3. European Commission. EU Trade Policy. Available online: https:/ / ec.europa.eu/trade/policy/ (accessed on 26 February 2021).

4. European Commission. International Affairs-Sanitary and Phytosanitary Measures. Available online: https://ec.europa.eu/ food/safety/international_affairs_en (accessed on 26 February 2021).

5. European Commission. General Food Law. Available online: https://ec.europa.eu/food/safety/general_food_law_en (accessed on 5 April 2021).

6. European Parliament and the Council of the European Union. Regulation (EC) No 178/2002 of the European Parliament and of the Council of 28 January 2002 Laying Down the General Principles and Requirements of Food Law, Establishing the European Food Safety Authority and Laying Down Procedures in Matters of Food Safety. Available online: https://eur-lex.europa.eu/ legal-content/EN/ALL/?uri=celex:32002R0178 (accessed on 10 July 2019).

7. European Commission. White Paper on Food Safety. COM (1999) 719 Final. Available online: https:/ / ec.europa.eu/food/sites/ food/files/safety/docs/gfl_white-paper_food-safety_2000_en.pdf (accessed on 23 August 2020).

8. United Nations. United Nations Conference on Trade and Development. International Classification of Non-Tariff Measures2019 Version. Available online: https://unctad.org/webflyer/international-classification-non-tariff-measures-2019-version (accessed on 29 April 2021).

9. Ederington, J.; Ruta, M. Non-Tariff Measures and the World Trading System; Policy Research Working Paper No. 7661; World Bank: Washington, DC, USA, 2016. Available online: https:/ / openknowledge.worldbank.org/handle/10986/24499 (accessed on 29 April 2021).

10. United States Trade Representative (USTR). Non-Tariff Barriers and Regulatory Issues. Available online: https:/ / ustr.gov/tradeagreements/free-trade-agreements/transatlantic-trade-and-investment-partnership-t-tip/t-tip-2 (accessed on 29 April 2021).

11. Organisation for Economic Co-Operation and Development (OECD). Non-Tariff Measures. Tariffs Are the Tip of the Iceberg: How behind the Border Issues Impact Trade. Available online: https://www.oecd.org/trade/topics/non-tariff-measures/ (accessed on 29 April 2021).

12. European Commission. Sustainable Agriculture in the CAP. Available online: https://ec.europa.eu/info/food-farming-fisheries/ sustainability/sustainable-cap_en (accessed on 5 April 2021). 
13. European Commission. Trade for All: European Commission Presents New Trade and Investment Strategy. News on 14 October 2015. Available online: https://trade.ec.europa.eu/doclib/press/index.cfm?id=1381 (accessed on 5 April 2021).

14. European Commission. Commissioner Malmström Unveils 15-Point Plan to Make EU Trade and Sustainable Development Chapters More Effective. News on 27 February 2018. Available online: https://trade.ec.europa.eu/doclib/press/index.cfm? id=1803\&title=Commissioner-Malmstr\%C3\%B6m-unveils-15-point-plan-to-make-EU-trade-and-sustainable-developmentchapters-more-effective (accessed on 5 April 2021).

15. European Commission. Sustainable Development. Available online: https://ec.europa.eu/trade/policy/policy-making/ sustainable-development/\#_trade-agreements (accessed on 5 April 2021).

16. European Commission. The European Commission's Priorities. Available online: https://ec.europa.eu/info/strategy_en (accessed on 5 April 2021).

17. European Commission. Political Guidelines of the Commission 2019-2024. Available online: https://ec.europa.eu/info/sites/ default/files / political-guidelines-next-commission_en_0.pdf (accessed on 5 April 2021).

18. European Commission. A European Green Deal. Available online: https://ec.europa.eu/info/strategy/priorities-2019-2024/ european-green-deal_en (accessed on 5 April 2021).

19. European Commission. What Is the European Green Deal? Available online: https://ec.europa.eu/commission/presscorner/ api/files/attachment/859152/What_is_the_European_Green_Deal_en.pdf.pdf (accessed on 5 April 2021).

20. European Commission. From Farm to Fork. Available online: https://ec.europa.eu/info/strategy/priorities-2019-2024/ european-green-deal/actions-being-taken-eu/farm-fork_en (accessed on 5 April 2021).

21. European Commission. Farm to Fork Strategy for a Fair, Healthy and Environmentally-Friendly Food System. Available online: https:/ / ec.europa.eu/food/farm2fork_en (accessed on 5 April 2021).

22. Jarzębowski, S. Integration of Food Supply Chain as an Element of Efficiency of Food Processing Industry; Warsaw University of Life Sciences: Warsaw, Poland, 2013.

23. Lambert, D.M.; Cooper, M.C. Issues in supply chain management. Ind. Mark. Manag. 2000, 29, 65-83. [CrossRef]

24. Christopher, M. Logistics and Supply Chain Management: Strategies for Reducing Cost and Improving Service, 2nd ed.; Financial Times Pitman Publishing: London, UK, 1998. [CrossRef]

25. Van der Vorst, J. Effective Food Supply Chains; Generating, Modelling and Evaluating Supply Chain Scenarios; Wageningen University: Wageningen, The Netherlands, 2000.

26. Tietenberg, T.L.; Lewis, L. Environmental \& Natural Resource Economics, 9th ed.; Pearson Education: Boston, MA, USA, 2009.

27. Kashmania, R.; Keenan, C.; Wells, R. Corporate environmental leadership: Drivers, characteristics, and examples. Environ. Qual. Manag. 2010, 19, 1-20. [CrossRef]

28. Jarzębowski, S.; Bourlakis, M.; Bezat-Jarzębowska, A. Short Food Supply Chains (SFSC) as Local and Sustainable Systems. Sustainability 2020, 12, 4715. [CrossRef]

29. Castillo, V.E.; Mollenkopf, D.A.; Bell, J.E.; Bozdogan, H. Supply Chain Integrity: A Key to Sustainable Supply Chain Management. J. Bus. Logist. 2018, 39, 38-56. [CrossRef]

30. Elkington, J. Cannibals with Forks: The Triple Bottom Line of the 21st Century; Capstone Publishing Limited: Oxford, UK, 1997.

31. Elkington, J. Enter the Triple Bottom Line. In The Triple Bottom Line: Does It All Add Up? Henriques, A., Richardson, J., Eds.; Earthscan: London, UK; Sterling, VA, USA, 2004; pp. 1-16.

32. Orlitzky, M.; Schmidt, F.L.; Rynes, S.L. Corporate Social and Financial Performance: A Meta-Analysis. Organ. Stud. 2003, 24, 403-441. [CrossRef]

33. Carter, C.R.; Rogers, D.S. A Framework of Sustainable Supply Chain Management: Moving Toward New Theory. Int. J. Phys. Distrib. Logist. Manag. 2008, 38, 360-387. [CrossRef]

34. Golicic, S.L.; Smith, C.D. A Meta-Analysis of Environmentally Sustainable Supply Chain Management Practices and Firm Performance. J. Supply Chain. Manag. 2013, 49, 78-95. [CrossRef]

35. Waller, M.A.; Fawcett, S.E.; Johnson, J.L. The Luxury Paradox: How Systems Thinking and Supply Chain Collaboration Can Bring Sustainability into Mainstream Practice. J. Bus. Logist. 2015, 36, 303-305. [CrossRef]

36. Pagell, M.; Wiengarten, F.; Fynes, B. Institutional Effects and the Decision to Make Environmental Investments. Int. J. Prod. Res. 2013, 51, 427-446. [CrossRef]

37. Carter, C.R.; Easton, P.L. Sustainable supply chain management: Evolution and future directions. Int. J. Phys. Distrib. Logist. Manag. 2011, 41, 46-62. [CrossRef]

38. Galli, F.; Brunori, G. (Eds.) Short Food Supply Chains as Drivers of Sustainable Development. Evidence Document; Document developed in the framework of the FP7 project FOODLINKS (GA No. 265287); Laboratorio di studi rurali Sismondi: Pisa, Italy, 2013.

39. Jarzębowski, S.; Pietrzyck, K. The concept of short supply chains in the food economy. In Proceedings of the International Scientific Conference on the Common Agricultural Policy for the European Union-The Present and the Future, Stare Jabłonki, Poland, 5-7 December 2017; Multi-Annual Programme 2015-2019, no 73.1. Wigier, M., Kowalski, A., Eds.; Institute of Agricultural and Food Economics, National Research Institute: Warsaw, Poland, 2019; pp. 196-208. [CrossRef]

40. Malak-Rawlikowska, A.; Majewski, E.; Wąs, A.; Borgen, S.O.; Csillag, P.; Donati, M.; Freeman, R.; Hoàng, V.; Lecoeur, J.L.; Mancini, M.C.; et al. Measuring the Economic, Environmental, and Social Sustainability of Short Food Supply Chains. Sustainability 2019, 11, 4004. [CrossRef] 
41. International Monetary Fund. Global Trade Liberalization and the Developing Countries. IMF Issues Brief 01/08. November 2001. Available online: https:/ / www.imf.org/external/np/exr/ib/2001/110801.htm (accessed on 30 July 2021).

42. World Bank Group. Stronger Open Trade Policies Enable Economic Growth for All. Results Briefs 3 April 2018. Available online: https:/ / www.worldbank.org/en/results/2018/04/03/stronger-open-trade-policies-enables-economic-growth-for-all (accessed on 30 July 2021).

43. United Nations. International Trade in Developing Economies. Available online: https://sdgpulse.unctad.org/trade-developingeconomies/\# (accessed on 30 July 2021).

44. European Commission. Trade as a Driver of Prosperity. Commission Staff Working Document Accompanying the Communication on Trade, Growth and World Affairs. Trade Policy as a Core Component of the EU's 2020 Strategy. SEC (2010) 1269 Final, 9 November 2010. Available online: http:/ / aei.pitt.edu/38023/ (accessed on 30 July 2021).

45. Porter, M.E.; van der Linde, C. Green and Competitive: Ending the Stalemate. Harv. Bus. Rev. 1995, 73, 120-134. Available online: https:/ / hbr.org/1995/09/green-and-competitive-ending-the-stalemate (accessed on 19 June 2021).

46. Kleindorfer, P.R.; Singhal, K.; Van Wasssenhove, L.N. Sustainable Operations Management. Prod. Oper. Manag. 2005, 14, 482-492. [CrossRef]

47. Pagell, M.; Wu, Z. Building a More Complete Theory of Sustainable Supply Chain Management Using Case Studies of 10 Exemplars. J. Supply Chain. Manag. 2009, 45, 37-56. [CrossRef]

48. Reuter, C.; Foerstl, K.; Hartmann, E.; Blome, C. Sustainable Global Supplier Management: The Role of Dynamic Capabilities in Achieving Competitive Advantage. J. Supply Chain. Manag. 2010, 46, 45-63. [CrossRef]

49. Thornton, L.M.; Autry, C.W.; Gligor, D.M.; Brik, A.B. Does Socially Responsible Supplier Selection Pay Off for Customer Firms? A Cross-Cultural Comparison. J. Supply Chain. Manag. 2013, 49, 66-89. [CrossRef]

50. Beckman, J.; Ivanic, M.; Jelliffe, J.L.; Baquedano, F.G.; Scott, S.G. Economic and Food Security Impacts of Agricultural Input Reduction Under the European Union Green Deal's Farm to Fork and Biodiversity Strategies; EB-30; U.S. Department of Agriculture, Economic Research Service: Washington, DC, USA, 2020. Available online: https://www.ers.usda.gov/publications/pub-details/?pubid= 99740 (accessed on 5 June 2021).

51. Grübler, J.; Stöllinger, R.; Tondl, G. Are EU Trade Agreements in Line with the European Green Deal? Available online: https:/ / wiiw.ac.at/are-eu-trade-agreements-in-line-with-the-european-green-deal-n-484.html (accessed on 5 June 2021).

52. Kettunen, M.; Bodin, E.; Davey, E.; Gionfra, S.; Charveriat, C. An EU Green Deal for Trade Policy and the Environment: Aligning Trade with Climate and Sustainable Development Objectives; Institute for European Environmental Policy (IEEP): Brussels, Belgium; London, UK, 2020. Available online: https:/ / eu.boell.org/en/2020/02/06/eu-green-deal-trade-policy-and-environment (accessed on 5 June 2021).

53. Dupré, M.; European Trade Policy and the Green Deal. Green Eur. J. 2020. Available online: https://www.greeneuropeanjournal. eu/european-trade-policy-and-the-green-deal/ (accessed on 5 June 2021).

54. Schrauwen, A. A Geopolitical Commission, a European Green Deal and Trade'. Leg. Issues Econ. Integr. 2020, 47, 1-7. Available online: https: / / hdl.handle.net/11245.1/95dd4684-e0f4-4177-a6b4-0bdd393b4a35 (accessed on 5 June 2021).

55. Schebesta, H.; Candel, J.J.L. Game-changing potential of the EU's Farm to Fork Strategy. Nat. Food 2020, 1, 586-588. [CrossRef]

56. Grimm, S.; Reiners, W.; Helwig, N.; Siddi, M.; Mourier, L. The Global Dimension of the European Green Deal: The EU as a Green Leader? The Multinational Development Policy Dialogue, KAS: Brussels, Belgium, 2021. Available online: https://www.die-gdi de/en/others-publications/article/the-global-dimension-of-the-european-green-deal-the-eu-as-a-green-leader/ (accessed on 5 June 2021).

57. Wolf, S.; Teitge, J.; Mielke, J.; Schütze, F.; Jaeger, C. The European Green Deal-More Than Climate Neutrality. Intereconomics 2021, 56, 99-107. [CrossRef] [PubMed]

58. Fuchs, R.; Brown, C.; Rounsevell, M. Europe's Green Deal offshores environmental damage to other nations. Nature 2020, 586, 671-673. [CrossRef]

59. Siddi, M. The European Green Deal: Assessing Its Current State and Future Implementation. FIIA Working Paper 114. Finnish Institute of International Affairs: Helsinki, Finland, 2020. Available online: https:/ / www.fiia.fi/en/publication/the-europeangreen-deal (accessed on 5 June 2021).

60. European Commission. Sustainable Development Goals. Available online: https://ec.europa.eu/info/strategy/internationalstrategies/sustainable-development-goals_en (accessed on 5 April 2021).

61. United Nations. 17 Goals to Transform Our World. Available online: https://www.un.org/sustainabledevelopment/ (accessed on 5 April 2021).

62. United Nations. Department of Economic and Social Affairs. Sustainable Development. The 17 Goals. Available online: https://sdgs.un.org/goals (accessed on 5 April 2021).

63. European Commission. Towards a Sustainable Food System. Available online: https://ec.europa.eu/info/researchand-innovation/strategy/support-policy-making/scientific-support-eu-policies/group-chief-scientific-advisors/towardssustainable-food-system_en (accessed on 5 April 2021).

64. Westhoek, H.; DG SANTE, European Commission. EU Farm to Fork Strategy: Promoting Sustainable Food Consumption and Facilitating the Shift to Healthy, Sustainable Diets. Presentation at Online-Webinar by Valumics: Putting Solutions on the Table. Successful Approaches and Interventions to Support more Sustainable Food Consumption Behaviors in the EU. 16 July 2020. Available online: https://valumics.eu/events/ (accessed on 5 April 2021). 
65. El Bilali, H.; Strassner, C.; Ben Hassen, T. Sustainable Agri-Food Systems: Environment, Economy, Society, and Policy. Sustainability 2021, 13, 6260. [CrossRef]

66. Association of German Chambers of Industry and Commerce e.V. The German Chambers of Commerce Abroad. Available online: https://www.ahk.de/en/ (accessed on 7 April 2021).

67. Association of German Chambers of Industry and Commerce e.V. AHK Annual Report 2019. Available online: https://www.ahk de/fileadmin/DEinternational/AHK_JB19_A4_Quer_RZ_a12-ONLINE_ENGLISH_1_.pdf (accessed on 7 April 2021).

68. German Federal Ministry for Economic Affairs and Energy (BMWi). Promotion for Foreign Trade and Invest. Available online: https://www.bmwi.de/Navigation/EN/Topic/topic.html?cl2Categories_LeadKeyword=au\%C3\%9Fenwirtschaftsfoerderung (accessed on 7 April 2021).

69. Association of German Chambers of Industry and Commerce e.V. AHK World Business Outlook-Spring 2021. Available online: https: / www.dihk.de/resource/blob/53220/cfc21a22a651745c6b33155100e1fcfc/ahk-world-business-outlook-fruehjahr2021englisch-data.pdf (accessed on 7 June 2021).

70. Association of German Chambers of Industry and Commerce e.V. German American Chambers of Commerce. Available online: https://www.ahk.de/en/usa (accessed on 7 April 2021).

71. Association of German Chambers of Industry and Commerce e.V. International Affairs. Available online: https://www.dihk.de/ de/themen-und-positionen/internationales (accessed on 10 April 2021). (In German).

72. Representative of German Industry and Trade (RGIT). Trade. Available online: https://www.rgit-usa.com/en/issues/trade/ (accessed on 10 April 2021).

73. Pilgrim, M.; Meier, R. National Chambers of Commerce: A Primer on the Organization and Role of Chamber Systems; Center for International Private Enterprise (CIPE): Washington, DC, USA, 1995.

74. Carlsson, U. (Ed.) Understanding Media and Information Literacy (MIL) in the Digital Age. A Question of Democracy; Department of Journalism, Media and Communication (JMG), University of Gothenburg: Göteborg, Sweden, Published 2019 by the UNESCO Chair on Freedom of Expression, Media Development and Global Policy. Available online: https://www.gu.se/jmg/ understanding-media-and-information-literacy-mil-in-the-digital-age (accessed on 10 April 2021).

75. Dalkey, N.C. The Delphi Method: An Experimental Study of Group Opinion; The RAND Corporation: Santa Monica, CA, USA, 1969. Available online: https:/ / www.rand.org/pubs/research_memoranda/RM5888.html (accessed on 13 September 2021).

76. Hasson, F.; Keeney, S. Enhancing rigour in the Delphi technique research. Technol. Forecast. Soc. Chang. 2011, 78, 1695-1704. [CrossRef]

77. Hasson, F.; Keeney, S.; McKenna, H. Research guidelines for the Delphi survey technique. J. Adv. Nurs. 2000, 32, 1008-1015. [CrossRef]

78. Okoli, C.; Pawlowski, S.D. The Delphi method as a research tool: An example, design considerations and applications. Inf. Manag. 2004, 42, 15-29. [CrossRef]

79. Auerbach, C.F.; Silverstein, L.B. Qualitative Data: An Introduction to Coding and Analysis; New York University Press: New York, NY, USA, 2003.

80. de Vreese, C.H. News Framing: Theory and Typology. Inf. Des. J. 2005, 13, 51-62. [CrossRef]

81. Prat, A.; Strömberg, D. The Political Economy of Mass Media; Discussion Paper No. 8246; Centre for Economic Policy Research: London, UK, 2011. Available online: https://cepr.org/active/publications/discussion_papers/dp.php?dpno=8246 (accessed on 28 August 2019).

82. Varner, I.I. The Theoretical Foundation for Intercultural Business Communication: A Conceptual Model. J. Bus. Commun. 2000, 37, 39-57. [CrossRef]

83. Jameson, D.A. Reconceptualizing Cultural Identity and Its Role in Intercultural Business Communication. J. Bus. Commun. 2007, 44, 199-235. [CrossRef]

84. Lauring, J.; Jonasson, C. Language use and communication in an international management setting: The power to misrecognize. HERMES J. Lang. Commun. Bus. 2017, 23, 199-208. [CrossRef]

85. Amann, B.; Jaussaud, J. (Eds.) Cross-Cultural Challenges in International Management, 1st ed.; Routledge: New York, NY, USA, 2020. [CrossRef]

86. Bausch, M.; Barmeyer, C.; Mayrhofer, U. Cultural challenges and quality management practices of a German multinational in Brazil. In Cross-Cultural Challenges in International Management, 1st ed.; Amann, B., Jaussaud, J., Eds.; Routledge: New York, NY, USA, 2020; pp. 74-93. [CrossRef]

87. Raab, V.; Petersen, B. Strengthening of the international dialog between industry and academia. In Quality and Risk Management in Agri-Food Chains; Petersen, B., Nüssel, M., Hamer, M., Eds.; Wageningen Academic Publishers: Wageningen, The Netherlands, 2014; pp. 266-271.

88. Education and Qualification Alliance SCE. Internationalisation. Available online: https://www.eqasce.eu/internationalization/ (accessed on 5 March 2021).

89. Education and Qualification Alliance SCE. EQA Qualification Programs. Available online: https://www.eqasce.eu/eqaqualification-programs / (accessed on 5 March 2021).

90. FAO. COVID-19 and the Risk to Food Supply Chains: How to Respond? FAO: Rome, Italy, 2020. [CrossRef] 
91. Rivera-Ferre, M.G.; López-i-Gelats, F.; Ravera, F.; Oteros-Rozas, E.; di Masso, M.; Binimelis, R.; El Bilali, H. The two-way relationship between food systems and the COVID19 pandemic: Causes and consequences. Agric. Syst. 2021, 191, 103134. [CrossRef]

92. Deconinck, K.; Avery, E.; Jackson, L.A. Food Supply Chains and Covid-19: Impacts and Policy Lessons. EuroChoices 2019, 19, 34-39. [CrossRef]

93. Chen, K.Z.; Mao, R. Fire lines as fault lines: Increased trade barriers during the COVID-19 pandemic further shatter the global food system. Food Secur. 2020, 12, 735-738. [CrossRef] [PubMed]

94. Pietrzyck, K.; Berke, N.; Wendel, V.; Steinhoff-Wagner, J.; Jarzebowski, S.; Petersen, B. Understanding the Importance of International Quality Standards Regarding Global Trade in Food and Agricultural Products: Analysis of the German Media. Agriculture 2021, 11, 328. [CrossRef]

95. Fleming, T. Models of Lifelong Learning: An Overview. In The Oxford Handbook of Lifelong Learning, 2nd ed.; London, M., Ed.; Oxford University Press: Oxford, UK, 2020. [CrossRef]

96. Quendler, E.; Lamb, M.J.; Driouech, N. Sustainable Education, Employability, and Job Prospects for Next Generations in the Digital Era. In The Oxford Handbook of Lifelong Learning, 2nd ed.; London, M., Ed.; Oxford University Press: Oxford, UK, 2020. [CrossRef]

97. Maclean, R.; Ordonez, V. Work, skills development for employability and education for sustainable development. Educ. Res. Policy Prac. 2007, 6, 123-140. [CrossRef]

98. European Union. Eurostat Statistics Explained. Glossary: Enterprise size. Available online: https://ec.europa.eu/eurostat/ statistics-explained /index.php?title=Glossary:Enterprise_size (accessed on 7 March 2021).

99. Lozowicka, B.; Kaczyński, P.; Rutkowska, E.; Jankowska, M.; Hrynko, I. Evaluation of pesticide residues in fruit from Poland and health risk assessment. Agric. Sci. 2013, 4, 106-111. [CrossRef]

100. United States Department of Agriculture. Foreign Agricultural Service (FAS). Stone Fruit Annual 2018. GAIN Report Number SP1820, 2018. Available online: https://apps.fas.usda.gov/newgainapi/api/Report/DownloadReportByFileName?fileName= Stone\%20Fruit\%20Annual_Madrid_EU-28_8-24-2018 (accessed on 28 August 2019).

101. Pietrzyck, K.; Petersen, B.; Jarzębowski, S. The Role of Quality Management in the Context of the Transatlantic Trade and Investment Partnership (TTIP): The Case of the Polish Agri-Food Sector. Int. J. Probl. Agric. Econ. 2018, 3, 94-110. [CrossRef]

102. Lehnert, S.; Schütz, V.; Nüssel, M. Development of quality strategies in complex customer-supplier relationships. In Quality and Risk Management in Agri-Food Chains; Petersen, B., Nüssel, M., Hamer, M., Eds.; Wageningen Academic Publishers: Wageningen, The Netherlands, 2014; pp. 39-43.

103. European Commission. Commission Expert Group on Trade and Sustainable Development (E03013). Available online: https: / / ec.europa.eu/transparency/expert-groups-register/screen/expert-groups/consult?lang=en\&groupID=3013 (accessed on 5 April 2021).

104. European Commission. Remarks by Executive Vice-President Dombrovskis on the Trade Policy Review Communication at the European Parliament's International Trade Committee. Speech on 24 February 2021. Available online: https:/ / ec.europa.eu/ commission/presscorner/detail/en/speech_21_817 (accessed on 5 April 2021).

105. European Commission. Trade Policy Review. An Open, Sustainable and Assertive Trade Policy. Available online: https: //trade.ec.europa.eu/doclib/docs/2021/april/tradoc_159541.0270_EN_05.pdf (accessed on 26 April 2021).

106. Pietrzyck, K.; Steinhoff-Wagner, J.; Jarzebowski, S.; Petersen, B. Building Bridges-International Quality Management of the Agri-Food Industry on Global Markets-Reflecting Free Trade Agreements: TTIP as an Example. In Heutige und zukünftige Herausforderungen an die Qualitätswissenschaft in Forschung und Praxis, Proceedings of the GQW-Jahrestagung, Erlangen, Germany, 2-3 March 2017; Otten, H., Götz, J., Pollak, S., Eds.; FAU University Press: Erlangen, Germany, 2017; pp. 185-208. (In German)

107. Pietrzyck, K.; Driouech, N.; Petersen, B. The Transatlantic Trade and Investment Partnership (TTIP): Threat or an opportunity for EU-Mediterranean agriculture and agri-food sector? An exploratory survey. In Proceedings of the International Scientific Conference on the Common Agricultural Policy for the European Union-The Present and the Future, Stare Jabłonki, Poland, 5-7 December 2017; Multi-Annual Programme 2015-2019, no 73.1; Wigier, M., Kowalski, A., Eds.; Institute of Agricultural and Food Economics, National Research Institut: Warsaw, Poland; pp. 177-195. [CrossRef] 